\title{
Corporate Characteristics and Sustainability Reporting Environmental Agencies' Moderating Effects
}

\author{
Alhassan Haladu Mohammed Haliru Beri \\ Tunku Puteri Intan Safinaz School of Accountancy (TISSA-UUM), College of Business, Universiti Utara, \\ Malaysia. \\ Department of Accountancy, School of Management Studies, Kano State Polytechnic, Kano State Nigeria.
}

\begin{abstract}
The major objective of the research is to examine the relationship between the corporate characteristics of firm age, audit firms and tax rate on the one hand and environmental reporting on the other, through environmental policy administrators. The study considers environmentally sensitive firms listed in the NSE for the 6-year period ranging from 2009 to 2014. Data of the selected sample were analyzed using Stata13 to produce statistical results. The outcome of evaluated data was very encouraging as it shows an average disclosure rate of $60.36 \%$ given by the simple average disclosure index. Besides, the discovery also pointed out that a significant relationship exists between corporate characteristics and sustainability reporting. Environmental reporting should be made mandatory and an effective and efficient enforcement of G4 be done, so that the positive trends in environmental reporting could be maintained and sustained. An analysis of the moderating influence of environmental protection agencies on environmental disclosure due to corporate characteristics and the test of G4 in a developing and Africa's largest economy is a new experience. The study was restricted to only environmentally sensitive firms listed in the NSE. Future studies could be extended to an entire economy and even make comparison with developed or other emerging economies.
\end{abstract}

Keywords: -big four, corporate characteristics, effective tax rate, environmental reporting, firm age, firm auditors, global reporting initiative (GRI), sustainability

\section{INTRODUCTION}

Environmental problems have globally become social, economic and political issues. High temperatures giving rise to greenhouse gases that has damaged greater portion of the ozone layer with subsequent consequences of climate change and rise in sea level, have become so serious that political organizations like the Green parties of the United Kingdom and United States have sprang up. The environment is a summation of bio-diversification of the planet like different plants, animals and microorganisms which necessitate preservation and conservation (Shah, 20140. The threat posed by climatic change has forced the accounting discipline to recognize and account for firms' operational effects on the environment to at least mitigate its effects on the environment (Creel, 2010; Beaudry, 2010). June 2016 according to the National Centers for Environmental Information (NCEI) of the United States, is the warmest June on record with average temperatures standing at $71.78^{\circ} \mathrm{F}\left(22.1^{\circ} \mathrm{C}\right)$ and with a precipitation of $2.46^{\prime}$ it proved the $14^{\text {th }}$ driest June on record (NOAA, 2016).

From accounting perspective environmental information disclosure or environmental reporting or sustainability reporting could be influence by many factors ranging from general contextual factors, to internal context, to corporate characteristics (Adams, 2002). Corporate characteristics include many company attributes like board characteristics, corporate economic performance, ownership structure, industrial type, firm size, auditing firms, effective tax rate, etc. The relationship between these factors and environmental information disclosure have been studied in the past. Adams (2002), Cormier, Magnan \& van Velthoven, (2005), ElijidoTen (2009), de Villiers, Naiker and van Staden, C. J. (2011) and Khan, Muttakin, and Siddiqui (2013); are all studies that have tested the relationship between environmental reporting and firm size. Similarly, Ahmad, Hassan, and Mohammad (2003), Ballou, Heitger, and Landes (2006), Bewley and Li (2000) and Sun, Salama, Hussainey, and Habbash (2010) have also examined the association of environmental reporting with auditors. The same could be said about the relationship between environmental reporting and tax rate (Adams et al., 2003). Results from these researches on the relationships was mixed showing direct, inverse, significant, insignificant, etc. relationships. Furthermore, most of these studies were conducted in developed economies. Those that looked at emerging economies did not only considers non-African economies but also based their works on environmental disclosure standards other than the GRI (Global Reporting Initiative). In particular only linear relationships have been tested by most of these studies with no moderating or mediating assessment. 
This research attempts to examine the relationship between firm age, audit firms and tax rate on the one hand and environmental reporting on the other, through environmental policy administrators. Environmental protection agencies could be found in many countries of the world. In Nigeria, the government specifically established the Department for Petroleum Resources (DPR) and National Environmental Standard and Regulations Enforcement Agency (NESREA) to regulate and monitor environmental issues for the oil and nonoil sectors of the economy respectively. The roles of these agencies cannot be overemphasized therefore, this research was primarily aimed at assessing the role of environmental agencies in emerging, developing and Africa's biggest economy on the relationship between corporate characteristics (firm age, audit firm and tax rate) and environmental information disclosure. Of the different studies conducted so far on sustainability reporting, hardly any of them analyzed this relationship using the 2013 version of GRI environmental disclosure standard (G4) which, provides for environmental reporting based on the triple bottom line (TBL) reporting principle (GRI, 2011). Geol (2010) and GRI (2013) showed that the TBL principle covers the three Ps of profit (economic), people (social) and plants (environmental).

It is hoped that the application of G4 and the examination of the relationship between the above named corporate characteristics and sustainability reporting brings out the strength or weaknesses of environmental protection agencies in relation to the environmental reporting determined by corporate characteristics. In this respect, the authorities may be able to map out appropriate measures for the roles of these agencies in reporting. Furthermore, the use of the G4 environmental disclosure standard and regulations is yet to be tested for an emerging and developing economy like Nigeria, results from this study would not only pinpoint the need or otherwise for the adoption of G4 by developing economies but also provide a platform for such test.

The research was arranged into five sections. The first part which is the introduction is a general background of the subject matter to be investigated with major issues, objectives and significance pointed out. The literature review is an analysis of past literatures on the study with emphasis on objectives, designs, theories, frameworks and discoveries. This was followed by the methodology which, spells out the population and sample covered by the research as well as the method of data collection and the tools of data analysis applied. Discussion of results constituted the fourth section. In this section scientific analysis of data was done and the findings noted. The final section is a summary and conclusion of the work. The major discoveries were outlined and recommendations on their implications made.

\section{REVIEW OF RELEVANT LITERATURE}

1.1 Firm Age

By simple logic it can be easily infer that a positive relationship should exists between fixed assets age and the extent of environmental reporting. In the absence of other determinants, firm age is a reliable basis for assessing a firm's environmental performance (Cormier et al., 2005). Cormier et al. (2005), concluded from their work that there is strong and consistent evidence that older firms reports more extensively on environmental issues. This relationship is positive and consistent. These results were arrived at by basing the study on the multi-theoretical lenses of economic, public pressure and institutional theories. Firm age is usually measured by computing the true age of the firm from the date of incorporation (Elijido-Ten, 2009). Elijido-Ten (2009) discovered that the average age of firms operating in the Malaysian economy is approximately 25 years in a comparison of Malaysian environmental reporting attitudes. The result indicate a positive and no significant relationship with environmental reporting. The study which was based on the stakeholder theory justified it on the basis of the significance of stakeholder involvement in the reporting process. The research used ordinary least square (OLS) regression to determine the relationship.

In their examination of the relationship between corporate social reporting (CRS) discoveries and ownership Khan et al. (2013) discovered mixed results with an inverse association on managerial ownership and a direct and significant relationship for public and foreign ownership. The legitimacy theory formed the backbone of their research. Firm age was around 24 years on average and the study showed significant relationship with firm age. Furthermore, using the agency theory and the dependency theory de Villiers et al. (2011) discusses firm age in relation to environmental disclosure. The use of the natural logarithm of firm age to measure age of firms through logistic regression resulted into a direct and significant association with environmental reporting.

\section{$2.2 \quad$ Audit Firm}

Adams' (2000) examination of the nature and extent of the internal, general and corporate characteristics determinants of environmental reporting, showed that existing theories fail to explain these determinants. The entire sample of the study were selected from firms in the United Kingdom and Germany. Though two of the strongest economies in the region (Europe) were used, stronger economies like France and Italy were overlooked. Thus seriously questioning the justification of the sample of the study. Ahmad et al. (2003), found a positive and significant relationship between environmental reporting and audit firm in the studying of the 
Malaysian economy. Examining motivations of disclosure, their work was based on the contracting and political cost theories. However, the research did not observed the most developed economy (Singapore) in the ASEAN region which comprises Brunei, Cambodia, Indonesia, Lao, Malaysia, Myanmar, Philippines, Singapore, Thailand and Vietnam. While the political cost theory could hold for audit firm it is very weak for effective tax rate.

Ballou, Heitger and Landes (2006), found no association between environmental reporting and the auditing process. The research questions the suitability of the criteria used and the reporting standards auditors should apply. An examination of the factors associated with environmental disclosure by Canadian manufacturing firms reveals a positive relationship between environmental reporting and media coverage, higher pollution propensity and political exposure (Bewley \& Li, 2000). To this extent $83 \%$ of firms in the economy was audited by quality auditing firms. The study was limited to a single economy and just one sector (manufacturing). Laying emphasis on audit committee meetings and applying OLS robust regression, a positive but insignificant relationship was discovered between environmental reporting and audit firms, earnings management and the impact of corporate mechanism on it (Sun et al. 2010). On average 4 meetings were held monthly by the audit committee. The study completely failed to consider the big four auditing firms of Pricewaterhousecopers (PWC), Deloitte, Ernst \& Young (EY) and KPMG. Alrazi, Sulaiman and Ahmad (2009) looked at the extent of changes in environmental reporting and the quality and quantity of environmental reporting significance in 1999, 2003 and 2006. Basing the work on social issue life cycle theory and applying content analysis, it was discovered that environmental reporting has increase to 67\% (2006) from 47\% (1999). There is however, low quality disclosure principally targeting "good corporate citizenship" image (Alrazi et al., 2009). The drawback here was the inconsistency in the period chosen. While a four-year gap was allowed for the first and second period, a three-year gap was found between the second and third period. Again only 96 firms were covered by the research and no standard environmental disclosure index was applied in the research. This result contradicts Brammer and Pavelin (2008) who showed that media publicity played no significant role in environmental reporting. Their result reveal that only $18 \%$ of environmental reporting audit was carried out on United Kingdom firms. This cross-sectional research made a review of environmental trends since the first environmental reporting in 1989 (Kolk, 2004). Environmental reporting not only continues to rise but now constituted both social and financial issues (Kolk, 2004). Kolk (2004) applied content analysis on a crosssectional case study. This is insufficient for a worldwide trend of environmental disclosure investigation. A survey of environmental practice on Egyptian companies showed significant differences in environmental reporting in the different sectors of the economy (Smith, Yahya \& Amiruddin, 2007). Thirty-four items of disclosure index were used but the entire study was limited to only the industrial sector of a single economy.

\subsection{Effective Tax Rate}

Tax is a very important aspect of consideration in corporate governance. The tax rate determines the tax burden of a firm and could have serious implications for management's objectives. When tax burdens are very high the authorities should adopt prudent fiscal positions to eliminate pressure for future increase, thus sustaining it at its current level or below (Schick, 2005). Lanis and Richardson (2012), arrived at an inverse and significant relationship between corporate social responsibility and tax aggressiveness. This contrasts with the findings of Muller and Kolk (2012) whose work discovered a positive relationship between multinational enterprises and effective tax rate. Moreover, their result showed that multinational enterprises that embark on corporate social responsibility pay more taxes than those that did not. Multinational enterprises also pays considerably higher taxes than their local counterpart (Muller \& Kolk, 2012). Ahmad et al. (2003) found a positive and significant relationship between environmental reporting and audit firm in their studying of the Malaysian economy but insignificant relationship with effective tax rate. The biggest problem with tax is that related with the tax risk of noncompliance. The board of any organization should therefore, be very good in tax risk management (Erle, 2008).

\section{$2.4 \quad$ Environmental Policy Administrators}

The role of environmental policy administrators or environmental agencies is of much significant in the relationship between corporate characteristics and environmental reporting. The major agencies for this study are Department for Petroleum Resources (DPR) and National Environmental Standard and Regulations Enforcement Agency (NESREA) and the institutional theory which seeks to evaluate the role of outside institutional or organizational pressure on the disclosure of environmental information, was of greater significance in examining this relationship.

Works by Bell and Lundblad (2011) and Ienciu (2012) have been based on the stakeholder theory while Ballou et al. (2006) used the political theory to examine organizational relationship with environmental reporting. 


\subsubsection{DPR}

DPR seeks compliance by companies in the oil \& gas industry on health, safety, and environmental laws for the industry. In effect it is actually an enforceable body of applicable environmental laws and effective regulatory oversight of the oil \& gas industry (Osu, 2012). The Agency has been empowered by law to oversee all environmental issues in the oil \& gas industry. The safety operation of companies in the industry is very difficult to monitor especially those operating offshore. A very good example of this monitoring was reported by Ikpe (2012), who claimed that it was reported that some individuals misled two indigenous companies to bury hazardous waste rather than disposing them through approved methods.

The important thing about DPR in terms of environmental disclosures is that effective monitoring and enforcement of sustainability standards and regulations in the industry could lead to more and better environmental disclosure. Improper monitoring however, may lead to less or no disclosure at all on environmental issues. Being the only body in the country responsible for this, information about its operation could only be obtained from it.

\subsubsection{EGASPIN}

Introduced in 1991 Environmental Guidelines and Standards for the Petroleum Industry in Nigeria (EGASPIN) is under the authority of the DPR in Nigeria (Ofuani, 2011). Operations in the Petroleum industry in Nigeria are complex. The entire operations involve processes from exploration, mining, transportation, and marketing which may lead to pollution. Generally, some of the statutes governing pollution in Nigeria are given in the table below:

Table 2.1
\begin{tabular}{|l|l|c|}
\hline S/N & \multicolumn{1}{|c|}{ ORDINANCES/DECREES/ACTS } & DATE \\
\hline 1. & Mineral Ordinance & 1914 \\
\hline 2. & Petroleum Act & 1990 \\
\hline 3. & Oil Pipeline Act & 1990 \\
\hline 4. & Federal Environmental Protection Agency Act & $\mathbf{1 9 9 0}$ \\
\hline 5. & Associated Gas Re-injection Act & $\mathbf{1 9 9 0}$ \\
\hline 6. & Guidelines and Standards for Environmental Pollution Control in & $\mathbf{1 9 9 1}$ \\
\hline & Nigeria & $\mathbf{1 9 9 2}$ \\
\hline 7. & Impact Assessment Decree & $\mathbf{1 9 9 0}$ \\
\hline 8. & Criminal Code & $\mathbf{1 9 9 0}$ \\
\hline 9. & Harmful Waste Act & $\mathbf{1 9 9 2}$ \\
\hline 10. & Sea Fisheries Decree & $\mathbf{1 9 9 0}$ \\
\hline 11. & Territorial Waste Act & $\mathbf{1 9 6 4 ~ \& ~ 1 9 6 7}$ \\
\hline 12. & Explosive Act & $\mathbf{1 9 6 9}$ \\
\hline 13. & Oil Terminal Dues Act & \\
\hline
\end{tabular}

Source: Ofuani, 2011

EGASPIN outlined some of the specific regulations about the petroleum industry. They include Petroleum (Drilling and Production) Regulation (1969), Mineral Oils (Safety) Regulations (1963), Petroleum Regulations (1967), Oil in Navigable Waters Decree no. 34/Regulation (1968), Oil Pipeline Ordinance Cap. 145 of 1956 as amended (1965) and Petroleum Refining Regulations (1974). The growing concern for environmental damages due to oil related pollution forced the DPR to issue:

...Interior guidelines concerning the monitoring, handling, treatment and disposal of effluents, oil spills and chemicals, drilling muds and drill cuttings by leases/oil operators. Tentative allowable limits of waste discharges into fresh waters, coastal waters, and offshore areas of operations were established (EGASPIN, 1991:1). 
EGASPIN (1991) is divided into 10 Parts as seen in Table 2.2. Table 2.2 Major Sections of EGASPIN (1991)

\begin{tabular}{|c|l|r|}
\hline PARTS & \multicolumn{1}{|c|}{ CONTENT } & \multicolumn{1}{|c|}{$\begin{array}{c}\text { PAGE } \\
\text { RANGE }\end{array}$} \\
\hline I & Introduction & $\mathbf{1 - 2}$ \\
\hline II & Exploration and Development Operations & $\mathbf{3 - 4 3}$ \\
\hline III & Production Operations & $\mathbf{4 4 - 6 2}$ \\
\hline IV & Terminal Operations & $\mathbf{6 1 - 7 0}$ \\
\hline V & Hydrocarbon Processing Operations & $\mathbf{7 1 - 1 0 9}$ \\
\hline VI & Oil and Gas Transportation & $\mathbf{1 1 0 - 1 1 9}$ \\
\hline VII & Marketing Operations & $\mathbf{1 2 0 - 1 3 1}$ \\
\hline VIII & Standardization of Environmental Abatement Procedures & $\mathbf{1 3 2 - 2 9 3}$ \\
\hline IX & Schedule of Implementation, Permits Enforcement Powers and Sanctions & $\mathbf{2 9 4 - 3 0 4}$ \\
\hline X & Definitions and Acronyms & $\mathbf{3 0 5 - 3 1 4}$ \\
\hline
\end{tabular}

Source: EGASPIN 1991

\subsubsection{NESREA}

Formed in 2006, NESREA was established by the NESREA Act (2007) and charged with the responsibility of protecting and developing the Nigerian environment by enforcing all "environmental laws, guidelines, policies, standards and regulations" and conventions on the environment endorsed by the federal government of Nigeria (nesrea.org, 2015), excluding the Upstream of the oil \& gas sector. It is an agency of the Federal Ministry of Environment responsible for enforcing laws, regulations, and standards in deterring individuals and business organizations from polluting and degrading the Nigerian environment with the exception of the upstream and midstream sectors of the oil \& gas industry. Its major responsibility includes the protection and development of the nation's environment, biodiversity, conservation and sustainable development. It is expected to encourage environmental technology through coordination and liaison with partners globally to enforce environmental, standards, rules, regulations, laws, policies, and guidelines. The more these objectives are upheld the better the disclosure of environmental information.

\subsubsection{National Environmental Standards and Regulations (NESR)}

To ensure proper management of the environment through National Environmental Policy, NESREA has developed some guidelines, which includes a number of policy strategies and management approaches designed to ensure that environmental concerns are considered in economic decision-making, major development projects, and proper management of national resources. To succeed the guideline was built on seven (7) Principles.

a. The Precautionary Principle

b. The Pollution Prevention Pays Principle

c. The Polluter Pays Principle

d. The User Pays Principle

e. The Principle of Integrational Equity

f. The Principle of Intra-generational Equity

g. The Subsidiary Principle

The major sections of the strategies for implementation of the National Environmental Policy are: Human Population, Culture, Housing and Human Settlements, Biological Diversity Management, Natural Resources Conservation, Land Use and Soil Conservation, Agriculture, Water Resources Management, Forestry, Wild Life and Protected Natural Areas, Marine and Coastal Area Resources, Mining and Natural Resources, Industry, Energy, Oil \& Gas, Construction, Health, Education, Transport and Communication Systems, Trade, Tourism and Science \& Technology. Other specific issues like disasters, Flood and Erosion, Sanitation and Wastemanagement, Air-pollution, Noise pollution, Occupational Health and Safety, etc. were equally treated.

\subsection{Model Design and Hypothesis Development}

Literatures on environmental reporting showed that there has been many studies between corporate characteristics and social reporting. Findings from such researches have been mixed. The emphasis however, is that most of the studies were conducted on economies outside Africa. Secondly, there are hardly any studies that have assess these relationships together with environmental agencies. Nigeria being Africa's largest 
economy stands as the best example for such research. This study therefore, investigates this relationship between the basis corporate attributes of firm age, audit firm and effective tax rate by trying to observe the moderating effects of environmental agencies may have on their relationship with environmental reporting. The study is based on the institutional theory which, states that the role of outside organizations pressure on firms could force them to make disclosures. In the context of this research environmental agencies, tax authorities (Federal Inland Revenue Service) and audit firms are all outside organizations that could apply undue pressure on firm's to make environmental disclosure. In this regard, the model was built to reflect the institutional theory. Thus the model below gives the relation for this research:

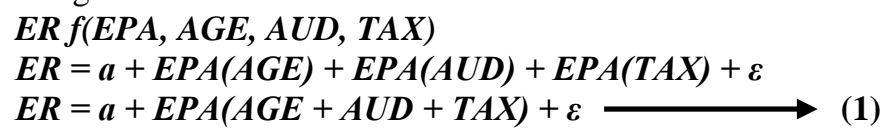$$
E R=a+E P A(A G E+A U D+T A X)+\varepsilon \longrightarrow(1)
$$

Where:

$\mathrm{ER}=\quad$ sustainability reporting

$\mathrm{EPA}=$ environmental policy agencies/administrators

$\mathrm{AGE}=$ firm age

AUD $=$ audit firm

TAX $=$ effective tax rate

$\mathrm{a}=$ constant term

$\varepsilon=\quad$ marginal error

The study therefore, proposes for the assertion that:

$\mathrm{Ho}_{2} \quad$ there is no significant relationship between the combined effects of corporate characteristics (firm size, audit firm \& effective tax rate) and environmental monitoring agencies, and sustainability reporting by listed firms in the NSE.

\section{METHODOLOGY}

The influence of corporate characteristics (firm age, audit firm and effective tax rate) on environmental reporting was examine for the entire Nigerian economy, and for the purpose of this study the economy has been classified into environmentally sensitive and non-environmentally sensitive sectors. In the non-environmentally sensitive sector there are seven industries forming $68.77 \%$ of firms quoted in the Nigerian Stock Exchange (NSE), while the environmentally sensitive sector has six industries with $31.23 \%$ of quoted firms (Table 3.1 ). However, the non-environmentally sensitive sector is dominated by financial $(57.89 \%)$ and services $(42.11 \%)$ industries which, have very low propensity of environmental pollution (Table 3.1). In this regard, the study considers environmentally sensitive sector as the population of this research. There are 69 quoted firms in the six industries in this sector (Table 3.1).

Table 3.1 Environmental Sectors of the Nigerian Economy

\begin{tabular}{|l|l|r|r|}
\hline S/N & \multicolumn{1}{|c|}{ Sectors } & $\begin{array}{c}\text { No. of } \\
\text { Quoted } \\
\text { Firms }\end{array}$ & Percentage \\
\hline \multicolumn{3}{|c|}{ Financial } \\
\hline \multicolumn{3}{|c|}{ Non-Environmentally Sensitive } \\
\hline 1. & Financial Services & 56 & 25.34 \\
\hline 2. & Mandatory Quotations & 22 & 9.95 \\
\hline 3. & Alternative Securities Markets (ASeM) & 10 & 4.52 \\
\hline Sub-Total & $\mathbf{8 8}$ & $\mathbf{3 9 . 8 1}$ \\
\hline \multicolumn{3}{|c|}{ Nonfinancial (Services) } \\
\hline 4. & Conglomerates & 6 & 2.71 \\
\hline 5. & Consumer Goods Communications \& Telecoms & 27 & 12.22 \\
\hline 6. & Information, Com & 4.98 \\
\hline 7. & Services & 20 & 9.05 \\
\hline Sub-Total & $\mathbf{6 4}$ & $\mathbf{2 8 . 9 6}$ \\
\hline Financial Industries (88/152*100) & $\mathbf{5 7 . 8 9}$ \\
\hline Services Industries (64/152*100) & $\mathbf{4 2 . 1 1}$ \\
\hline \multicolumn{3}{|c|}{ Environmentally Sensitive } \\
\hline 8. & Agriculture & 5 & 2.26 \\
\hline 9. & Construction/Real Estate & 10 & 4.53 \\
\hline 10. & Healthcare & 10 & 4.53 \\
\hline 11. & Industrial Goods & 6 & 12.67 \\
\hline 12. & Natural Resources & 28 & 4.53 \\
\hline 13. & Oil \& Gas & 10 \\
\hline
\end{tabular}




\begin{tabular}{|l|c|r|}
\hline Sub-Total & 69 & 31.23 \\
\hline Grand Total & $\mathbf{2 2 1}$ & $\mathbf{1 0 0}$ \\
\hline
\end{tabular}

Source: NSE FactBook 2011/12 \& 2012/13

By far the greatest pollutant and socially risky sector, the oil and gas sector has only ten quoted firms (Ayoola \& Olasanmi, 2013; Hope for Niger Delta, 2010; Kadafa, 2012; Ndubusi \& Asia, 2007; Offiong, 2007). This number seemed small for the economy's biggest polluter and contribution to government revenue, compared to the scores of firms operating in the industry. Besides, major pollutant like Royal Dutch/Shell are not quoted in the NSE. Therefore, the researcher added twelve more companies from industries that are operating in Nigeria and which published their financial statements in the website. The population of the study was therefore, defined in terms of the sixty-nine environmentally sensitive quoted firms plus the twelve added petroleum companies that published on the internet. This gives a total population of 81 firms.

The application of Collins \& Schultz formulae at 5\% marginal error resulted in a sample size of 67 firms (Enahoro, 2009; Nyor, 2008). This constituted $82.72 \%$ of the population of the study. To eliminate any biasness $82.72 \%$ of sample was selected form the population of each of the six industries in the sector. The six industries covers mainly manufacturing and petroleum sectors. Specifically, six industries made up these sectors. They include agriculture, construction/real estate, healthcare, industrial goods, natural resources and oil and gas. These industries are environmentally sensitive because they generally influence adversely more on the environmental through effluents and emissions from their economic operations (Enahoro, 2009; Owolabi, 2007). Longitudinally, a six-year period of recent years was covered. The years $(2009,2010,2011,2012,2013$ \& 2014) were considered for the study because it is believed that data for this period for all firms in the sample would be available. Three major variables were used for this research work. Details of them is given in Table 3.2 below.

Table 3.2 Variables of the Research

\begin{tabular}{|l|l|l|l|}
\hline \multicolumn{1}{|c|}{ Variable Type } & \multicolumn{2}{c|}{ Variable Name } & \multicolumn{1}{c|}{ Measuring Index } \\
\hline Dependent Variable & Environmental Reporting & SADI \\
\hline Independent Variable & $\begin{array}{l}\text { Corporate } \\
\text { Characteristics }\end{array}$ & Firm Age & Log of number of years \\
\cline { 3 - 4 } & & Audit Firm & Dummies \\
\cline { 3 - 4 } & & Effective Tax Rate & Tax expense/PAT \\
\hline Moderating Variable & Environmental Policy Administrators & MVI \\
\hline
\end{tabular}

Source: Computed by Researcher

The simple average disclosure index (SADI) was arrived at by applying 33 disclosure item of the G4 disclosure standard. For each disclosure a score of 1 mark was awarded while non-disclosure attracts 0 score. A ratio of the total score obtained to the total expected score (33) give the SADI which, has a minimum of 0 score and a maximum score of 1 . Corporate characteristics used are firm age, audit firm and effective tax rate (Table 3.2). Firm age was given as the natural logarithm of the number of years (Khan et al., 2013). Audit firm was measured using dummies of 0 and 1 . For firms audited by the big-four a dummy of one score (1) was awarded and those not audited by the big-four were scored zero (0) (Ahmad, et al., 2003). Effective tax rate was defined as a ratio of tax payable to profit after tax (PAT). This shows the proportion of a company's disposable income that goes as tax. This measurement was adopted to avoid collinearity in the data observation as all registered companies in Nigeria have identical tax rate of 30\% (non-oil \& gas) and $85 \%$ (oil \& gas). The mean value index (MVI) was measured by a Likert scale that score compliance with major disclosure by firms from environmental agencies view point. Each compliance disclosure was scored between 1 and 5 depending on the level of disclosure and 0 score for non-disclosure. The MVI was computed by taking a ratio of total compliance disclosure score to total expected disclosure expressed as 5 giving a magnitude of 0 to 5 with 0 representing the lowest value of the MVI and 5 the highest value.

Descriptive analysis, correlation matrix and linear (robust) regression were the analytical tools used to determine the level of disclosure, existence and direction of relationships and significance of the relationships for the model of the study. These tools also served as the bases for hypothesis tests.

\section{DISCUSSION OF RESULTS}

4.1 Analysis of Results

The focus of analysis for this study is on the relationship between the combined effort of corporate characteristics and environmental agencies and sustainability reporting. Diagnostic tests conducted on the variables show acceptable results (Table 4.1). Normality values for all the variables fell within affordable range. Skewness was below 2 and kurtosis below 10. This is an indication of the normality of the data used for this research (Tsafe, 2013). 
Table 4.1

Diagnostic Tests

\begin{tabular}{|l|r|r|r|r|}
\hline \multicolumn{1}{|c|}{ Diagnosis } & SADI & Firm Age & Audit Firm & $\begin{array}{c}\text { Effective Tax } \\
\text { Rate }\end{array}$ \\
\hline Skewness & -0.3470 & -0.0941 & -0.3240 & -0.6775 \\
\hline Kurtosis & 2.4374 & 2.5921 & 1.3767 & 4.2576 \\
\hline
\end{tabular}

Source: Stata13

Descriptive analysis showed a high level of sustainability disclosure of $60.36 \%$. This disclosure rate was recorded within a disclosure range $6.06 \%$ minimum and $100 \%$ maximum with a standard deviation of 0.25 (Table 4.2). This level of disclosure is highly encouraging considering the fact that environmental disclosure is voluntary. Furthermore, with the Nigerian economy plagued with corruption, it is surprising that firms in polluted industries complied to this level with environmental reporting standards. This is an indication that if encourage, such firms could perform better. Encouragements like environmental disclosure incentives and the introduction of mandatory disclosure may greatly assist in the level of sustainability.

The mean age of firms in the observation was 41 years with the youngest firms aged at 3 years and the oldest at 139 years. This range show the relative experience in environmental disclosure between the firms. While some firms virtually lacks any experience, others are heavily loaded with environmental experience. The result summary also reveal that $62.69 \%$ of environmentally sensitive farms are audited by the big four. In other words, only $37.31 \%$ of firms in the sector are audited by auditing firms other than the big four. This could be one the major reasons why discloser on sustainability issues is so high. The fact that the big four have high standards suggests quality verification of firms' annual sustainability reports.

The tax rate effectively stood at an average of $27.42 \%$. This implies that on average firm's spends about $27 \%$ of their disposable income on tax. Though the minimum rate showed firm's claims for tax reliefs, the maximum rate showed that some firms' spend as high as $224 \%$ of their disposable income on tax expenses. This is not encouraging at all as investors will be left with no retained earnings. This situation does not auger well for firm's growth and development. It also pushes firms to resort to external borrowing for expansion purposes which, come at a cost.

The correlation matrix index show that an acceptable relationship with no elements of collinearity exists between all the variables. None of the indices is up to the multicollinearity level of $80 \%$ or $90 \%$ for all the relationships (Table 4.3). The linear regression results gives an overall significant value (f-value) of $1.22 \%$. This showed a significant relationship between corporate characteristics and environmental reporting at 5\% level of significance with an $\mathrm{R}^{2}$ value of $2.7 \%$. Of much significance however, are the individual coefficients and p-values. For firm age it shows that for every one year change in firms' age, environmental reporting must change by $10.61 \%$. While for audit firm and effective tax rate the rate of change are $3.17 \%$ and $7.5 \%$ respectively. Thus giving the relationship as:

$$
E R=0.3557+\operatorname{Epa}(0.1061 \text { Age }-0.0317 \text { Aud }+0.0757 \text { Tax }) \longrightarrow \text { (2) }
$$

A critical look of the t-value reveals a positive relationship exists between firm age and reporting (2.37). The same could not be said of the relationship between the big four and reporting as the relationship is not only inverse $(-1.19)$ but also insignificant $(\mathrm{p}=0.234)$. A direct and significant relationship exists between effective tax rate and environmental information disclosure as $t$ and $\mathrm{p}$ results shows values of 2.10 and 0.036 respectively (Table 4.2). In short, there are more disclosure on environmental issues with older firms and when the tax burden is higher. On the other hand the relationship between the big four and environmental reporting is inverse. This however, is of no significance as the result shows.

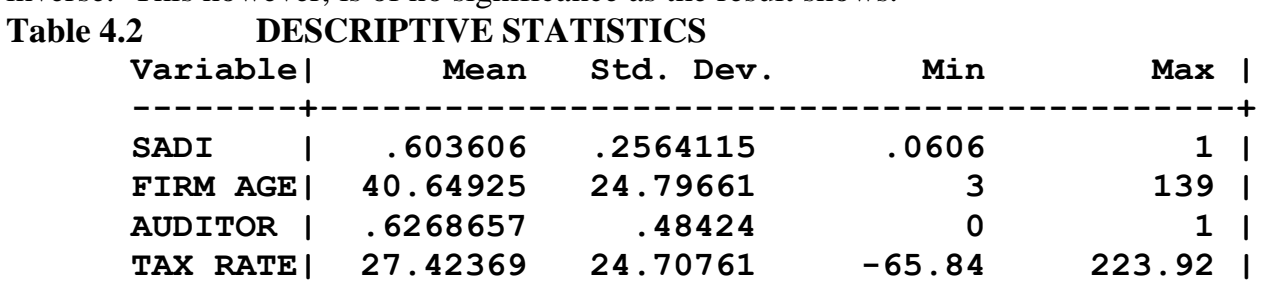

Source: Stata13 
Table 4.3 CORRELATION MATRIX

\begin{tabular}{|c|c|c|c|c|c|}
\hline & I & SADI & AGE & AUDITOR & TAX RATE \\
\hline FIRM AGE & 1 & 0.1191 & 1.0000 & & \\
\hline AUDIT FIRM & i & -0.0327 & 0.1014 & 1.0000 & \\
\hline TAX RATE & i & 0.1047 & 0.0703 & 0.1447 & 1.0000 \\
\hline
\end{tabular}

Source: Stata13

Table 4.4

\begin{tabular}{|c|c|c|c|}
\hline \multicolumn{4}{|c|}{ Simple Linear Regression } \\
\hline Prob > F & $=0.0122$ & & \\
\hline R-squared & 0.0270 & & \\
\hline sadi & Coef. & t & $P>|t|$ \\
\hline FIRM AGE & 1060997 & 237 & 0.018 \\
\hline AUDITOR & -.031696 & -1.19 & 0.234 \\
\hline TAX RATE & .0757254 & 2.10 & 0.036 \\
\hline cons & .3556764 & 4.30 & 0.000 \\
\hline
\end{tabular}

Source: Stata13

4.2 Test of Hypothesis

The f-statistics of 0.0122 indicates that a significant relationship exists between corporate characteristics and environmental reporting. Therefore, the null hypothesis should be rejected. This implies that changes in firm age, audit firm and effective tax rate have significant influence on environmental reporting.

\section{V. \\ 5.1 Summary \\ SUMMARY, CONCLUSION AND RECOMMENDATIONS}

The threat of environmental pollution attained an unprecedented heights this year as the month of June recorded the warmest temperature in history. It is therefore, imperative to examine the relationship between corporate characteristics and sustainability reporting which this work based itself upon. Previous studies have showed mixed results on this relationship. Of greater significance however, is the role of environmental agencies in the relationship. The research tests this relationship as influenced by the role of environmental policy administrators.

Concentrating attention on environmentally sensitive firms the study applied simple average index and mean value index to measure major variables of the research. Through descriptive statistics and regression analysis the results showed very high levels of environmental reporting and a significant relationship between corporate characteristics of firm age, audit firm and effective tax rate in conjunction with environmental agencies on the one hand and sustainability reporting on the other.

\subsection{Conclusion and Findings}

The discussion above showed that the relationship between environmental reporting and corporate characteristics is strong and have significant influence. Specifically results from the analysis showed the following facts.

a. There is a very high sustainability disclosure rate by environmentally sensitive firms listed in the NSE. The rate which stood at $60.36 \%$ is very high even at developed economics standard. It should be noted that Nigeria is not only a developing economy but an economy that does not recognize mandatory environmental disclosure. The standard applied for this research is the G4 environmental disclosure standard based on the TBL principle. It therefore, means that firms in Nigeria meet to a large extent all the economic, social and environmental disclosure standards.

b. This significant relationship show the efficiency of environmental agencies (DPR \& NESREA) in environmental reporting. They ensure a high level of reporting by firms in the economy. Though they go by their own regulations, guidelines and standard; the results show high level of compliance with international standard. This is an indication that the standards under their individual jurisdiction matches international standards.

c. Most firms in the sectors have an average forty years of experience. Even though there are firms that can boast of only three years existence some have experience of up to 139 years. This is an indication that 
Nigeria firms have come of age and are therefore, expected to have the experience and technical expertise required in environmental reporting. The introduction of mandatory sustainability reporting is therefore, long overdue.

d. Over $62 \%$ of firms in the pollutant sector are audited by internationally acclaimed and recognized auditing firms. This makes financial statements in the sector to be reliable for decision making. Moreover, it could be the major motivation for firms to embark on environmental sporting as they provide both quality and international standard reports.

e. The average tax rate is low compared to the statutory ones. The statutory tax rate for firms in Nigeria is $30 \%$ (non-oil sector) and $85 \%$ (oil sector). It is therefore, expected that firms tax rate should lie between the ranges of $30 \%$ to $85 \%$. However, our result showed a rate of about $27 \%$ on disposable income. This implies that the average taxable rate could even be lower. This is a big incentive for disclosure.

f. On individual basis a positive and significant relationship exists between firm age and sustainability reporting. The same was true of the relationship between environmental and effective tax rate. However, the relationship between the audit firm and sustainability reporting was inverse and not significant.

\subsection{Recommendations}

On the basis of the discoveries the study advised that the current tempo of environmental disclosure be maintained. The authorities should introduce measures and incentives that attracts more disclosure of environmental nature. Incentives such as allowances or reliefs for environmental disclosure. There also the need to introduce legislation that makes environmental disclosure mandatory as against the current voluntary status so as to sustain the current high level.

The need for the introduction of mandatory environmental disclosure is backed by facts like the high level of current disclosure rate, long years of experience in their operations and the advantage of being audited by reputable accounting firms. Two of firms' characteristics have significant relationship with environmental disclosure with audit firms having an insignificant relationship. Encouragements should be given to indigenous audit firms to upgrade their standards so that this relationship becomes significant. The introduction of special tax reliefs as conditions for environmental disclosure may also encourage firms to embark on environmental reporting.

5.4 Contributions and Limitations of the Study

The study has made enormous contributions to knowledge by examining environmental sustainability reporting through environmental policy administrators and basing disclosures on G4 which, is the latest version of GRI (the most wildly accepted environmental disclosure guidelines and standards). The study covers the largest economy in a developing continent like Africa. However, it was restricted to only environmentally sensitive firms listed in the NSE. Future studies could be extended to an entire economy and even make comparison with developed or other emerging economies.

\section{REFERENCES}

[1] Adams, C. A. (2002). Internal organizational factors influencing corporate social and ethical reporting: Beyond current theorizing. Accounting, Auditing \& Accountability Journal, 15(2); 223-250. http://www.emeraldsight.com/095-3574.htm

[2] Ahmad, Z., Hassan, S. \& Mohammad, J. (2003). Determinants of environmental reporting in Malaysia. International Journal of Business Studies. 11(1), 69-90.

[3] Alrazi, B., Sulaiman, M. \& Ahmad, N. N. N. (2009). A longitudinal examination of environmental reporting practices in Malaysia. Internal Journal of Business. 11(1); 37-72. https://www.researchgate.net/publication

[4] Ballou, B., Heitger, D. L. \& Landes, C. E. (December 2006). The future of corporate sustainability reporting - a rapid growing assurance opportunity. Journal of Accountancy, 202(6); 65-74. http://www.starbucks.com

[5] Bell, J. \& Lundblad, H. (2011). A comparison of ExxonMobil's sustainability reporting to outcomes. Journal of Applied Business and Economics. 12(1); 17-29.

[6] Bewley K, \& Li, Y. (2000). Disclosure of environmental information by Canadian manufacturing companies: a voluntary disclosure perspective. Advances in Environmental Accounting and Management, Vol. 1, Freedman, M. Jaggi, B. (Eds.). JAI Press: Greenwich. 201-226.

[7] Brammer, S. \& Pavelin, S. (2008, February). Factors influencing the quality of corporate environmental disclosure. Business Strategy and the Environment, 17, 120-136. https://www.researchgate.net/publication 
[8] Cormier, D., Magnan, M., and Van Velthoven, B. (2005). Environmental disclosure quality in large German companies: economic incentives, public pressures or institutional conditions? European Accounting Review, 14(1) 3-39.

[9] de Villiers, C., Naiker, V. \& van Staden, C. J. (2011). The effects of board characteristics on firm's environmental performance. Journal of Management, DOI: 10.1177/0149206311411506.

[10] Elijido-Ten, E. O. (2009, January). Can stakeholder theory add to our understanding of Malaysian environmental reporting attitudes? Researchgate: Malaysian Accounting Reviews, 8(2); 85-110. https://www.researchgate.net/publication/259767251

[11] Enahoro, J. A. (2009). Design and bases of environmental accounting in oil and gas and manufacturing sectors in Nigeria. A PhD Thesis submitted to Department of Accounting, College of Business and Social Sciences, Covenant University, Ota, Nigeria.

[12] Erle, B. (2008). Tax risk management and board responsibility. Springer, 205-220.

[13] Geol, P. (July 2010). Triple Bottom Line reporting: an analytical approach for corporate sustainability. Journal of Finance, Accounting, and Management. 1(1); 27-42.

[14] Global Reporting Initiative (2011). GRI and ISA 26000: How to use the GRI guidelines in conjunction with ISO 26000. ISBN: 978-90-8866-041-2. http://www.globalreporting.org

[15] Global Reporting Initiative (2013). G4 Sustainability reporting: Reporting principles and standard disclosures. The Netherlands. http://www.globalreporting.org

[16] Ienciu, I. A. (2012). The contribution of the environmental management system to ensuring environmental reporting. Studia UBB, ECONOMICA. 52(2); 49-57.

[17] Ikpe, S. (2011). Government steps up regulatory compliance in the oil and gas industry... Safety and environmental team re-strategizes on regulatory oversight. DPR News. A quarterly Journal of the Department of Petroleum Resources. 6(2).

[18] Khan, A., Muttakin, M. B. \& Siddiqui, J. (2013). Corporate governance and corporate social responsibility disclosures: evidence from an emerging economy. Journal of Business Ethics, 114:207223; DOI 10.1007/s10551-012-1336-0.

[19] Kolk, A. (2004) 'A decade of sustainability reporting: developments and significance'. International Journal of Environment and Sustainable Development, 3(1), 51-64.

[20] Lanis, R. \& Richardson, G. (2012). Corporate social responsibility and tax aggressiveness: an empirical analysis. Journal of Accounting and Public Policy, 31; 86-108.

[21] Muller, A. \& Kolk, A. (2015). Responsible tax as corporate social responsibility: the case of multinational enterprises and effective tax in India. Business \& Society, 54(4); 435-463.

[22] National Oceanic and Atmospheric Administration (NOAA 2016, June). Climate monitoring. www.ncdc.noaa.gov/climate-monitoring/

[23] NESREA.org (2015, May $7^{\text {th }}$ ). The establishment of the National Environmental Standards and Regulations Enforcement Agency of Nigeria. http://www.nesrea.org/about.php

[24] NSE FactBook (2011/2012). Nigerian Stock Exchange. www.http://nigerianstockexchange.com

[25] NSE FactBook (2012/2013). Nigerian Stock Exchange.

[26] Nyor, T. (2008). Assessment of the level of accounting information disclosed in the financial statements of Nigerian banks. A Ph.D. Thesis presented to the Department of Economics and Management Sciences, Nigerian Defence Academy, Kaduna.

[27] Ofuani, A. I. (2011). Environmental regulation of offshore (E \& P) waste management in Nigeria: how effective. Law Environment and Development (LEAD) Journal. 7(2); 79-94.

[28] Osu, P. (2012). DPR repositions for improved regulation of the oil and gas industry... Mandates additional requirements for petroleum product depots. DPR News. A quarterly Journal of the Department of Petroleum Resources. 7(1).

[29] Owolabi, A. A. (2007). Incorporating environmental costs into Nigeria oil and gas accounting. Ph.D. thesis submitted to the department of management and accounting. Faculty of Administration, Obafemi Awolowo University; Ile-Ife, Nigeria.

[30] Rizk, R., Dixon, R. \& Woodhead, A. (2008). Corporate social and environmental reporting: a survey of disclosure practices in Egypt. Social Responsibility Journal, 4(3); 306-323.

[31] Schick, A. (2005). Sustainable budget policy: concepts and approaches. OECD Journal on Budgeting, 1, 1608-7143.

[32] Shah, A. (2014, January 19). Global Issues: Social, political, economic, and environmental issues that affect us all. Global Issues. http://www.globalissues.org/about

[33] Smith, M., Yahya, K. \& Amiruddin, A. M. (2007). Environmental disclosure and performance reporting in Malaysia. Asian Review of Accounting. 15(2); 185-199.

[34] Sun, N., Salama, A., Hussainey, K. \& Habbash, M. (2010). Corporate environmental disclosure, corporate governance and earnings management. Managerial Auditing Journal, 25(7); 679-700. 
[35] Tsafe, B. M. (2013). Stakeholders' perceptions on corporate governance constitution and their implications on board performance. Ph.D. thesis Othman Yeop Abdullah Graduate School of Business, Universiti Utara, Malaysia. 